\title{
EFFECT OF GRAZING TIME ON PRODUCTIVE PERFORMANCE OF GOAT IN HALAIB - SHALATEEN REGION
}

\author{
M.S. Nassar \\ Animal and Poultry Nutrition Department, Animal and Poultry Nutrition Division, Desert Research \\ Center, P.O. Code 11753 Mataria,Cairo,Egypt.
}

Email:mahmoud_nassar1974@yahoo.com

(Received 3/11/2019, accepted 17/12/2019)

\section{SUMMARY}

$\mathrm{T}$ his study was carried out at Ras Hadraba Valley region (Shalateen Research Station, Desert Research Center). Thirty female local goats, 2-4 years were randomly distributed into three similar groups with $17.74 \pm 0.57 \mathrm{Kg}$. the treatments included: 1 st group (G1) without grazing and feed $1 \%$ concentrate feed mixture of total requirements as recommended by NRC (1981) plus berseem hay ad libitum. The 2 nd $(\mathrm{G} 2)$ and 3rd (G3) groups were fed $1 \%$ concentrate feed mixture and allowed daily to graze on Panicum turgidum as a basal range plant for 4,8 hours for G2 and G3, respectively. Nutrients digestibility, feeding values, does reproductive and productive performance and also economic feasibility were studied through this investigation. Dry matter intake (DMI) of P. turgidum during pregnancy period was increased by different level of grazing time between G3 and G2 while (DMI) were higher in G1 which fed berseem hay ad libitum as roughage. Moreover, expressing it as ( $g$ /kg BW/ hour) was different between all treatments. The greatest intake $(\mathrm{g} / \mathrm{kg} \mathrm{BW} /$ hour) was recorded for goats in G2 followed by G1 and G3.From the results of chemical composition; found that (G1) obtained the highest amount of CP, CF and NDF followed by the G3 and G2. Total dry matter intake was affected among treatments, mainly owing to the difference in roughage intake. It was observed that (G1) showed the highest value of TDMI, CP, CF and NDF. The same trend was observed during lactation period Nutrients digestibility showed that, DM, OM, CP, and CF digestibility were affected significantly $(\mathrm{P} \leq 0.05)$ among treatments. It was observed that goat $\mathrm{G} 3$ showed the highest digestion coefficients of DM, OM, and CF.TDN and DCP of G3 showed the highest $(\mathrm{P}<0.05)$ value of TDN\% (71.78) comparing with G1 and G2. But grazing for 4hours (G2) resulted in a lowest value of TDN intake either as g/ kg BW (16.88). DCP expressed as percentage $(\mathrm{g} / \mathrm{kg} \mathrm{BW})$ were not affected $(\mathrm{P}<0.05)$ by time spent for grazing. It can be seen that, G1 showed the highest $(\mathrm{P}<0.05)$ value of DCP \% (12.08) comparing with G1 and G2. But grazing for 4hours (G2) resulted in a lowest value of DCP intake either as g/ kg BW (1.77). During early pregnancy (EP) body weight change was insignificant decreased as grazing time. The highest value of BWC as a percent of IBW in (EP) was recorded for G1 (11.15\%), followed by G3 (7.23 \%) and G2 $(6.13 \%)$.Through pregnancy overall periods, BWC was significantly $(\mathrm{P} \leq 0.05)$ affected by grazing time, where the highest value was recorded for G3 followed by G2 and G1.Birth weight of kids varied insignificantly among groups. Birth weights of kids were 1.71, 1.52, and $1.44 \mathrm{~kg}$ for G3, G1and G2, respectively. During early lactation Does lost weight, while in late lactation there were no loses of does weight on G1 and G3 although that there were loses of does weight on G2 only. Daily (BWC) at late lactation were insignificantly among all treatments. Data of kidding live born were 9, 7 and 7 for G1, G2 and G3 respectively. while the much weaned kids were in G1 (6) than G2 (5) and G3 (2).The yields of kids born $\mathrm{kg}$ per 100 serviced does were 136.8, 121.1 and 100.8 for G1, G3 and G2, respectively, while Kids weaned kg per100 serviced does were higher in G1 (305.4) than G2 (277) and G3 (106). The relative milk yield of G2 and G3 at early lactation was 84.72 and $58.39 \%$ compared to G1 (100\%), respectively. In late lactation the relative milk yield was 76.94and $69.44 \%$ compared to G1 (100\%). The total relative milk yield showed the same trend of early and late lactation which was 81.21 and $63.40 \%$ for G2 and G3 compared to G1 (100\%), respectively. Weaning weight showed a different trend of kids was 5.54, 5.30, and $5.09 \mathrm{~kg}$ for G2, G3and G1, respectively. However overall changes (0-16 wks.) were differed among all treatments. Average daily gain was between (0-16 wks.) was as follows 36.61, 32.06 and 31.88 (g/day) for $\mathrm{G} 2$, G3and G1 respectively. The economic evaluation was calculated for both pregnancy and milk lactation separately. From these results, we conclude that all groups were uneconomic; it led to economic inefficiency for female goats during pregnancy and births. Having in milk production G1 was economically feasible for milk return duo to increased milk production and payed back in term of money; however the G2 and G3 was more efficient in term of net milk revenue as a percent of feeding cost. And 
return (offspring + milk) was higher in G1 than G2 and G3 this is due to higher number of kids and milk production. Net revenue, EP / Doe was higher in G2 and the next G3 this is due to the decrease cost feeding values, while G1, whose cost was high. It could be concluded that G2 (4 hours grazing time) through production cycle period is feasible rather than G1 (zero hours grazing time) or G3 (8 hours grazing time). Also, using of supplementary feeding system for lactating goats wasn't economically feasible with such genetically marginal lactating goats.

Keywords: Natural desert ranges, grazing time, supplementary feeding and goat production.

\section{INTRODUCTION}

Goats account for about $30 \%$ of Africa's ruminant livestock and produce about 17 and $12 \%$ of its meat and milk, respectively, Goats are particularly important in marginal agricultural land areas, especially in arid and semi-arid areas, which together hold 64\% of goat population (Lebbie, 2004). Goats are playing an important role in the social and economic life in desert region which they are more adaptable than other ruminant species at this area (Silanikove, 2000). Goats have certain physical characteristics i.e., bipedal grazing stance, upper mobile lip, and prehensile tongue that provide them with the necessary grazing skills to select preferred species or to adapt to different feed resources according to its availability (Taylor and Kothmann, 1990). Ruminant production in most countries of tropical Africa relies heavily on the availability of grazing land.The quality and quantity of grasses available as feed are low as a result of a climate characterized by a relatively long-dry season that alternates with a short-rainy season. During the rainy season, although range plants grow rapidly, their nutritive value may be high at the start (Tedonkeng Pamo et al., 2006). Rangelands occupy $44 \%$ of the earth's land surface, in arid and semi-arid areas expansion of cultivated areas has increasingly restricted rangelands to the less productive locations such as high mountains and sparse vegetation consisting mainly of ligneous plants containing relatively high proportions of antinutritive phenolic compounds (Nolan et al., 1997).

Halaib-Shalateen triangle region has a vital and strategic importance to Egypt as a border area between Egypt and Sudan. This region is a mountainous desert with several valleys dissecting mountains. The source of income of most inhabitants depends mainly on range animals where goats are the most dominant livestock production system in this region. This region is mostly characterized with low and erratic rainfall which resulted in drought and consequently a poor range condition, especially through summer season. The range vegetation in Halaib-Shalateen triangle region is considered the basic renewable source of ruminants feed, nevertheless, the short duration of rains precipitation, long drought periods, shortage of forage production, seasonal starvation of animals, unavailability of feed concentrates which brought from the Nile valley, unavailability of drinking water for animals during the dry season and improper economic inter-relationship between animal productivity and potential utilization of range plants (El Shaer et al., 1997).

Grazing is a good way to improve the feed self-sufficiency of dairy goat farms. To help farmers to optimise their management choices, the impact of grazing management practices on intake, performance and grazing behaviour of dairy goats need to be quantified (Charpentie et al., 2019) Nevertheless, daily access time to pasture may also be a time constraint for grazing goats that need time to graze as the other ruminants. Conversely, small ruminants, and particularly lactating dairy goats, are only allowed to graze during the daytime, with these animals being kept indoors at night for preventing theft, predation, diseases, or health problems, but also to facilitate farmers' work organisation (TovarLuna et al., 2011). Black Bedouins goats (or Baladi goats as it is called in Egypt) are the most numerous and known by being highly fertile and prolific, non-seasonal breeders, and able to produce year-round (Galal, 1987).On the other hand, Panicum turgidum is the main dominant forage crop in Wadi Hederba where most of Bedouins animals rely on such plant throughout the year (El Shaer, 2002). Panicum turgidum, the most important forage plant in Halaib region from stand point of drought tolerant, high nutritive value, and palatability had the highest coverage of $5.51 \%$, (Mohamed, 2018). These rangelands areas represent a major source of income for many of the region's residents. Lately, the region starts to face overgrazing by increasing the animal numbers in the rangelands particularly after the recent development in the Shalateen-Abou-Ramad-Halaib region. Results also showed that Panicum turgidum had the highest dry matter forage production of $85.9 \mathrm{~kg} \mathrm{DM} / \mathrm{ha}$ and $75.25 \mathrm{~kg} \mathrm{DM} / \mathrm{ha}$ for spring of 2014 and spring of 2015, respectively (Mohamed et al., 2019). 
Drought in the summer/autumn severely affects sheep production systems due to low pasture growth and quality, thus limiting the feed available for grazing ewes during the pre-mating and mating periods. Feeding ewes at a level below maintenance results in loss of live weight (LW) and body condition score (BCS) and, during mating, severely reduces ovulation rate and subsequent lambing percentage (McWilliam et al., 2005). Nutrition plays an essential and special role in the systems of goat farming for the following main reasons. Firstly, it is the production factor that goat farmers or keepers can act on easily and rapidly (amounts of feeds, composition of diets, on-pasture goat management). Secondly the management of feeding in goat flocks depends on vegetal mass production and rangeland, pasture and crop by-product management. Thirdly feeding directly impacts the other components of goat production systems, such as pathological conditions and the reproductive performance of flocks. (Morand-Fehr, 2005) Generally, animal resources and their productivity systems in Egypt are generally constrained by main four limiting factors: environment, range resources, nutritional constraints, beside socio-economic stresses (Hegazi et al., 2005).

The objective of the present study was to investigate the effect of grazing time on production and reproduction performance of local goats which raised on grazing ranges of Hederba valley, ShalateenHalaib region as far as supplemental feeding is very important defence against scarcity of forage in this area.

\section{MATERIALS AND METHODS}

\section{Study Location:}

The current experiment was conducted at Ras Hadraba valley, which is located between longitudes $\left(36^{\circ}, 52^{\prime}, 676^{\prime \prime} \& 36^{\circ}, 45^{\prime}, 002^{\prime \prime}\right)$ and latitudes $\left(21^{\circ}, 59^{\prime}, 795^{\prime \prime} \& 22^{\circ}, 59^{\prime}, 992^{\prime \prime}\right.$. This investigation was carried out at Shalateen Research Station, Desert Research Center (DRC), Ministry of Agriculture and Land Reclamation, Red Sea Governorate, Egypt. The area located between Red Sea in the East and River Nile in the West, about $1400 \mathrm{~km}$ South East from Cairo city, (latitude 22, 00, $720 \mathrm{~N}$, longitude $36,48,955 \mathrm{E})$. It is classified as an arid region with average ambient air temperatures of the study location are $35^{\circ} \mathrm{C}$ and $22^{\circ} \mathrm{C}$, and relative humidity values are $37 \%$ and $43 \%$ for the summer and winter seasons, respectively (EMA, 1991). The average annual precipitation is $58.5 \mathrm{~mm}$, and mostly as erratic showers in November and December. Water resources are meager and available only to nomadic inhabitants and their animals from shallow wells. Thus, sedentary agricultural activities are absent and livestock grazing on rangelands is considered the only option of livelihood for the farmers.

\section{Animals, feeds and design:}

Thirty female local goats, 2-4 years were randomly distributed into three groups with average live weight; $17.74 \pm 0.57 \mathrm{Kg}$, through factorial design experiment. All groups were mated by the same bucks, 3-5 average years old.

The treatments included: $1^{\text {st }}$ group $(\mathrm{G} 1)$ without grazing and feed $1 \%$ concentrate feed mixture of total requirements as recommended by (NRC 1981) plus berseem hay ad libitum. The $2^{\text {nd }}(\mathrm{G} 2)$ and $3^{\text {rd }}$ (G3) groups were feed $1 \%$ concentrate feed mixture and allowed daily to graze on $P$. turgidum as a basal range plant for 4,8 hour for G2 and G3, respectively.

Supplementary feed was offered daily for does after grazing time. Goat of all groups were kept under the same managerial and hygienic conditions and animals were allowed to drink water (desalination Seawater) ad lib at 08.00 a.m. (just before grazing), 2.00 p.m. at farm break and 6.00 p.m. after coming back from grazing. Mineral blocks (Biomix 331, Bicochema Products) were freely available. Animals were weighed at the beginning of the experiment and biweekly thought the whole experimental period. Animals were weighed at 7.00 a.m. after fasting period of 12 hours

\section{Reproductive performance:}

Reproductive performance of dose for all groups was evaluated through calculating the following indexes; 1) numbers of does joined, conceived, non-conceived, aborted and kidded, and those returned to estrus after matting season; 2) Prolificacy as number of kids born and weaned in relation to the number of does joined or conceived, and 3) growth performance of kids and litter size at birth and 
weaning. Moreover, total milk production was recorded weekly after separating does from their offspring (kids) temporary for one day in individual pens.

\section{Digestibility trials:}

The digestibility trial was carried out using four goats chosen randomly from each group. The digestibility trials were conducted during the grazing period. The preliminary period lasted for 14 days and followed by 7 days as a collection period. Animals were housed in individual pens and fitted with collection bags (harness). During the collection period bags were daily emptied at 7.00 a.m. before grazing and at 6 p.m. after return back to the farm. Feces were quantitatively collected from each animal and ten percent of each fecal sample was taken and dried at $65^{\circ} \mathrm{C}$ for a constant weight and ground to pass through a $1.0 \mathrm{~mm}$ mesh screen for chemical composition.

\section{Analytical procedures:}

Chemical analysis of grazed range plant samples, feed ingredients, concentrate feed mixture (CFM) and feces were carried out in Animal Nutrition Laboratory of Desert Research Center according to the AOAC (1990). Neutral detergent fiber (NDF) was determined according to the procedures of (Goering and Van Soet, 1970).

Dry matter intake and nutrients digestibility of the range were determined using the internal marker (acid insoluble ash; A.I.A) indicator technique as followed by (Van Keulen and Young, 1977). The general equation used for calculating dry matter intake was as follows:

Marker in range plant $=$ Marker in feces - Marker in concentrate diet

Estimated DMI, g/day = Total marker in pasture intake / Concentration of marker in pasture on dry basis

Apparent digestibility coefficients of the remind nutrients were calculated using the ordinary methods of AOAC (1990).

\section{Statistical analysis:}

Data obtained in this study was statistically analyzed according to Statistical Analysis System SAS (2004). Where the following model was used:

$$
Y_{i j}=\mu+F_{i}+E_{i j}
$$

Where, $\quad \mathrm{Y}_{\mathrm{ij}}=$ experimental observations

$$
\begin{aligned}
\mu & =\text { the overall mean } \\
\mathrm{F}_{\mathrm{i}} & =\text { the fixed effect of treatments }(\mathrm{i}=1, \ldots 3) \\
\mathrm{E}_{\mathrm{ij}} & =\text { random error }
\end{aligned}
$$

Differences in mean values between treatments were compared by Duncan's multiple range test (Duncan, 1955).

\section{RESULTS AND DISCUSSION}

\section{Chemical composition:}

In a field experiment conducted in Wadi Hederbah, Panicum turgidum was the dominant plant species over all the area in dry and wet seasons. In addition, it had the highest fresh and dry forage production during dry and wet seasons as found by (Badway, 2005) and (Nassar, 2008).

The chemical compositions of the experimental feeds are presented in Table (1). The chemical composition indicated that the crude protein content of both concentrate feed mixture (CFM) and 
Table (1): Chemical composition, DM basis of range plants and feed ingredients consumed by goats.

\begin{tabular}{lllllll}
\multicolumn{1}{c}{ goats. } & \multicolumn{6}{c}{ Proximate analysis, DM basis } \\
\cline { 2 - 7 } Item & DM & OM & Ash & CP & CF & NDF \\
\hline Concentrate feed mixture & 92.36 & 90.31 & 9.69 & 14.89 & 10.59 & 41.44 \\
Panicum turgidum & 93.15 & 90.44 & 9.56 & 6.76 & 30.49 & 78.61 \\
Berseem hay & 93.29 & 90.89 & 9.11 & 13.94 & 30.67 & 73.12 \\
\hline
\end{tabular}

Berseem hay as legumes was higher than that of $P$. turgidum as grass. On the contrary, CF and NDF for Berseem hay and P. turgidum was almost higher. The high coverage and abundance percentage of Panicum turgidum versus the other range plants could be attributed to its high NDF, ADF and ADL percentages which reduce the plant palatability and consequently increase its abundance in the range (El Shaer et al., 1997).

\section{Voluntary feed intake during pregnancy and lactation period:}

Data of voluntary feed intake for goat group during pregnancy and lactation period are illustrated in Table (2). It seems that, dry matter intake (DMI) of $P$. turgidum during pregnancy period was increased

Table (2): Voluntary feed intake consumed by goats during pregnancy and lactation period.

\begin{tabular}{|c|c|c|c|}
\hline \multirow[t]{2}{*}{ Item } & \multicolumn{3}{|c|}{ Experimental group } \\
\hline & G1 & G2 & G3 \\
\hline \multicolumn{4}{|c|}{ DM intake during pregnancy period: } \\
\hline Roughage, g/ kg BW & 23.05 & 17.96 & 20.41 \\
\hline $\mathrm{g} / \mathrm{kg} \mathrm{BW} /$ hour & 2.88 & 4.49 & 2.55 \\
\hline $\mathrm{CP}$ & 3.22 & 1.21 & 1.38 \\
\hline $\mathrm{CF}$ & 7.07 & 5.48 & 6.22 \\
\hline NDF & 16.85 & 14.12 & 16.04 \\
\hline Conc., g/ kg BW & 9.99 & 9.98 & 9.99 \\
\hline $\mathrm{CP}$ & 1.49 & 1.49 & 1.49 \\
\hline $\mathrm{CF}$ & 1.06 & 1.06 & 1.06 \\
\hline NDF & 4.14 & 4.14 & 4.14 \\
\hline Total, g/ kg BW & 33.03 & 27.95 & 30.40 \\
\hline $\mathrm{CP}$ & 4.71 & 2.70 & 2.87 \\
\hline $\mathrm{CF}$ & 8.13 & 6.54 & 7.28 \\
\hline $\mathrm{NDF}$ & 20.99 & 18.26 & 20.18 \\
\hline \multicolumn{4}{|c|}{ DM intake during lactation period: } \\
\hline Roughage, g/ kg BW & 29.02 & 17.74 & 22.37 \\
\hline $\mathrm{g} / \mathrm{kg} \mathrm{BW} /$ hour & 3.63 & 4.44 & 2.80 \\
\hline $\mathrm{CP}$ & 4.05 & 1.20 & 1.51 \\
\hline $\mathrm{CF}$ & 8.90 & 5.41 & 6.82 \\
\hline NDF & 21.22 & 13.94 & 17.59 \\
\hline Conc., g/ kg BW & 10.32 & 9.75 & 9.55 \\
\hline $\mathrm{CP}$ & 1.53 & 1.45 & 1.42 \\
\hline $\mathrm{CF}$ & 1.09 & 1.03 & 1.01 \\
\hline NDF & 4.28 & 4.04 & 3.96 \\
\hline Total, g/ kg BW & 39.34 & 27.49 & 31.92 \\
\hline $\mathrm{CP}$ & 5.58 & 2.65 & 2.93 \\
\hline $\mathrm{CF}$ & 9.99 & 6.44 & 7.83 \\
\hline NDF & 25.5 & 17.98 & 21.55 \\
\hline
\end{tabular}

G1: zero hour grazing time; G2: 4 hour grazing time; G3:8 hour grazing time.

by different level of grazing time between G3 and G2 while (DMI) were higher in G1 which fed berseem hay ad libitum as roughage. The greatest intake of Roughage (g/ kg BW) was recorded for goats in G1 (23.05) followed by G3 (20.41), whereas the lowest value was recorded by. G2 (17.96) 
Moreover, expressing it as $(\mathrm{g} / \mathrm{kg} \mathrm{BW} / \mathrm{hour})$ was different between all treatments. The greatest intake (g/kg BW/hour) was recorded for goats in G2 (4.49) followed by G1 (2.88), whereas the lowest value was recorded by G3 (2.55).From the results of chemical composition, found that (G1) obtained the highest amount of $\mathrm{CP}, \mathrm{CF}$ and $\mathrm{NDF}$ followed by the G3 and G2. While all groups' feed $1 \%$ concentrates feed mixture of total requirements as recommended by (NRC, 1981) Therefore, there are no differences between foods for convergence of weights between groups. Total dry matter intake was affected among treatments, mainly owing to the difference in roughage intake. It was observed that (G1) showed the highest value of TDMI, CP, CF and NDF mean values were 33.03, 4.71, 8.13 and $20.99 \mathrm{~g} / \mathrm{kg} \mathrm{BW}$.

The same trend was observed during lactation period where found that dry matter intake (DMI) of $P$. turgidum was increased by different level of grazing time between G3 and G2 while (DMI) were higher in G1 which fed berseem hay ad libitum as roughage. The greatest intake of Roughage $(\mathrm{g} / \mathrm{kg}$ BW) was recorded for goats in G1 (29.02) followed by G3 (22.37), whereas the lowest value was recorded by $\mathrm{G} 2$ (17.74). Moreover, expressing it as $(\mathrm{g} / \mathrm{kg} \mathrm{BW} /$ hour) was different between all treatments. The greatest intake (g $/ \mathrm{kg} \mathrm{BW/} \mathrm{hour)} \mathrm{was} \mathrm{recorded} \mathrm{for} \mathrm{goats} \mathrm{in} \mathrm{G2} \mathrm{(4.44)} \mathrm{followed} \mathrm{by} \mathrm{G1}$ (3.63), whereas the lowest value was recorded by G3 (2.80).From the results of chemical composition, found that (G1) obtained the highest amount of CP, CF and NDF followed by the G3 and G2. While all groups' feed $1 \%$ concentrates feed mixture of total requirements as recommended by (NRC, 1981). Therefore, there are no differences between foods for convergence of weights between groups. Total dry matter intake was affected among treatments, mainly owing to the difference in roughage intake. It was observed that (G1) showed the highest value of TDMI, CP, CF and NDF. Mean values were 39.34, $5.58,9.99$ and $25.5(\mathrm{~g} / \mathrm{kg} \mathrm{BW})$. The present results were in agreement with that reported by (Keli et al., 2017) who found no effect of access time on pasture intake, between $22 \mathrm{~h}$ and $8 \mathrm{~h} / \mathrm{d}$ or between $8 \mathrm{~h}$ and $6 \mathrm{~h} / \mathrm{d}$ ), probably due to a high supplementation level and consequently a low pasture intake. The decrease in pasture intake, when access time was restricted from 11 to $7 \mathrm{~h} / \mathrm{d}$, was significant $(-433 \mathrm{~g}$ $\mathrm{DM} / \mathrm{d}$, i.e. $18 \%$ or $108 \mathrm{~g} \mathrm{DM} / \mathrm{d}$ per hour of reduction of access time). The reduction of pasture intake with restriction of access time has already been observed in grazing goats but generally to a lesser extent (Charpentier, et al., 2019). On the other hand, (Tovar-Luna et al., 2011) reported a decrease in pasture intake of $36 \mathrm{~g} \mathrm{DM} / \mathrm{d}$ per hour of access time less when access time decreased from $24 \mathrm{~h}$ to 12 $\mathrm{h} / \mathrm{d}$.

palatability of plants which varied from season to season and from location to another depending on several factors, i.e. climatic factors, plant association, communities and animal species (El- Shaer et al., 1997). Also, (Erlinger et al., 1990) found basically to the grazing animal, that their daily forage intake is regulated by bite size, biting rate and grazing time In addition, (Chen et al., 2013) found that, the restricted grazing times had a significant impact on intake time, resting time, ruminating time, bite rate and movement. As the grazing time decreased, the proportion of time spent on intake, bite rate and grazing velocity significantly $(\mathrm{P}<0.05)$ increased, but resting and ruminating time clearly $(\mathrm{P}<0.05)$ decreased.

\section{Nutrients digestibility and nutritive values:}

Data of the nutrients digestibility (Table 3) showed that, DM, OM, CP, and CF digestibility were affected significantly $(\mathrm{P} \leq 0.05)$ among treatments. It was observed that goat $\mathrm{G} 3$ showed the highest digestion coefficients of DM, OM, and CF; being 72.83, 74.62, and 77.42\%, respectively. The lowest digestion coefficients DM, OM, CP, and CF $(64.74,65.71,67.95$ and $66.90 \%$ were recorded with G2 (4 hours grazing time), while G1 (zero hours grazing time) digestion coefficient of CP was higher than that of G3 and G2 being 73.89, 70.26 and $67.95 \%$ respectively. Reducing the allowed grazing time could presumably also mimic a situation where length of daytime is a constraint for animals with high nutritional requirements that need longer grazing times (Gibb et al., 1999). The present result of the OM digestibility was not in accordance with that found by (Charpentier and Delagarde 2018) where of the selected pasture OM was higher digested when animals access grazing for $4 \mathrm{~h}$ than $8 \mathrm{~h}$.

Data of the nutritive values expressed as total digestible nutrients (TDN) and digestible crude protein (DCP) are presented in Table 3. It can be seen that, diet of G3 showed the highest $(\mathrm{P}<0.05)$ value of TDN\% (71.78) comparing with the other two comparable diets (G1 and G2). But grazing for 4hours (G2) resulted in a lowest-value of TDN intake either as g/ kg BW (16.88). On the other hand, $\mathrm{DCP}$ expressed as percentage $(\mathrm{g} / \mathrm{kg} \mathrm{BW})$ were not affected $(\mathrm{P}<0.05)$ by time spent for grazing. It can be seen that, G1 showed the highest $(\mathrm{P}<0.05)$ value of DCP \% (12.08) comparing with the other two 
comparable diets (G1 and G2). But grazing for 4hours (G2) resulted in a lowest-value of DCP intake either as $\mathrm{g} / \mathrm{kg} \mathrm{BW}$ (1.77). The present results of digestion coefficients of all nutrients and also live body weight were reflected on the nutritive values. (Claps et al., 1997) indicate that the nutritive value of the diet of grazing goats is higher than that of the zero grazing goats. The lesser intake of the former is compensated by the greater nutritive value of the herbage. This does not exclude, however, that environmental conditions, temperature, humidity could have limited grazing time and thus herbage intake. Moreover, total grazing time may have been limited by an increased requirement for ruminating activity and idling i.e., non-grazing, non-ruminating activity within the total time budget of the animal (Gibb et al., 1999). While restricted grazing time system can guarantee lambs both access to pastures and abundant energy requirements (Wang et al., 2015).

Table (3): Nutrients digestibility and nutritive values as affected grazing time for does.

\begin{tabular}{lcccc}
\hline \multirow{2}{*}{ Item } & \multicolumn{4}{c}{ Experimental group } \\
\cline { 2 - 5 } & G1 & G2 & G3 & \pm SE \\
\hline Nutrients Digestibility, \% & $70.99^{\mathrm{a}}$ & $64.74^{\mathrm{b}}$ & $72.83^{\mathrm{a}}$ & 1.17 \\
DM & $71.15^{\mathrm{b}}$ & $65.71^{\mathrm{c}}$ & $74.62^{\mathrm{a}}$ & 1.23 \\
OM & $73.89^{\mathrm{a}}$ & $67.95^{\mathrm{b}}$ & $70.26^{\mathrm{ab}}$ & 1.14 \\
CP & $74.48^{\mathrm{a}}$ & $66.90^{\mathrm{b}}$ & $77.42^{\mathrm{a}}$ & 1.79 \\
CF & 67.87 & 60.40 & 67.05 & 1.77 \\
NDF & & & \\
Nutritive values: & & & \\
Total digestible nutrients: & $23.36^{\mathrm{a}}$ & $16.88^{\mathrm{b}}$ & $21.03^{\mathrm{ab}}$ & \\
g/ kg BW & $66.67^{\mathrm{b}}$ & $63.43^{\mathrm{b}}$ & $71.78^{\mathrm{a}}$ & \\
\% & & & & \\
Digestible crude protein: & $4.24^{\mathrm{a}}$ & $1.77^{\mathrm{b}}$ & $1.96^{\mathrm{b}}$ & 0.34 \\
g/ kg BW & $12.08^{\mathrm{a}}$ & $6.72^{\mathrm{b}}$ & $6.74^{\mathrm{b}}$ & \\
$\%$ &
\end{tabular}

Means in the same row with different superscripts differ significantly $(P \unlhd 0.05)$

G1: zero hour grazing time; G2: 4 hour grazing time; G3:8 hour grazing time.

\section{Body weight change during pregnancy:}

Changes in live body weight of does during pregnancy in all experimental groups are shown in Table 4. Pregnancy intervals were calculated to the nearest week from the actual kidding date of each doe. Initial body weight of does within each treatment was insignificant and averaged 18.75, 17.95 and $17.43 \mathrm{~kg}$ for does fed G1, G2 and G3, respectively.

During early pregnancy (Pregnant +90 days) body weight change was insignificant decreased as grazing time. The highest value of BWC as a percent of IBW in early pregnancy (EP) was recorded for G1 (11.15\%), followed by G3 $(7.23 \%)$ and G2 $(6.13 \%)$, which could be attributed to less range nutrients supply for G3 and G2 from ranges according to grazing time and grazing activity for goats which resulted in lower body weight up to 90 days of pregnancy. (Nassar 2008) found that during early pregnancy (first three months), live body weight and body weight changes were affected significantly $(\mathrm{P} \leq 0.05)$ by level of supplementation.

During late pregnancy (LP) live body weight was insignificant and it is considered equal as grazing time and body weight changes were affected significantly $(\mathrm{P} \leq 0.05)$ by grazing time where the highest body weight change in (L.P) was recorded for G3 $(3.22 \mathrm{~kg})$ followed by G2 $(2.09 \mathrm{~kg})$ and G1 $(1.06 \mathrm{~kg})$.

Through pregnancy overall periods, BWC was significantly $(\mathrm{P} \leq 0.05)$ affected by grazing time, where the highest value was recorded for G3 (4.48 kg), followed by G2 (3.19 kg) and G1 (3.15 kg). These results agreed with those reported by (Soder et al., 1995) indicated that un-supplemented ewes lost more body weight and body condition score than supplemented ewes. Less body weight and body condition loss in the supplemented ewes may have been due to factors other than the influence of supplementation on forage intake, such as increased energy or protein intake. The lower average weight 
gain of pregnant does on natural pasture treatment could possibly be attributed to the poor accessibility of natural pasture goats to most browse species (Akingbade et al., 2004).

Live body weight of does recorded just on the first day after kidding as a percent of IBW were 0.96 $\%, 6.80 \%$ and $9.06 \%$ for does fed G1, G2 and G3, respectively. Weight losses at kidding are the summation of the offspring weight, placentas and fetal fluids. Most differences among does weight change might be due to the increases in both fetal fluids and placentas. However, the energy value and protein content of forage may not meet the high nutritional requirements of animals, which limit weight gain .( Garcez et al., 2019). Therefore, feeding of grazing goats and sheep with concentrate supplement may be suggested to optimize growth performance, improved growth rate of goats and sheep under grazing condition. However, animals lost live weight without supplementation under the same feeding regime. (Salim et al., 2002).

Birth weight of kids varied insignificantly among groups. Birth weights of kids were 1.71, 1.52, and $1.44 \mathrm{~kg}$ for G3, G1and G2, respectively. Birth weight of kids was expressed as a percent of body weight of does; being $6.81 \%$ to $7.90 \%$ for does before kidding and from $7.51 \%$ to $9.10 \%$ for does after kidding. (Hossain et al., 2003) declared that birth weight of kids increased as the levels of dietary energy supplementation was increased and the mean values were $0.55,0.63$ and $0.75 \mathrm{~kg}$ for low, medium and high energy supplemented diets, respectively. Because protein deficiency in diet may lead to reduced forage intake and consequently reduced performance (Taylor et al., 2002). Therefore, the lambs that grazed for $8 \mathrm{~h} / \mathrm{d}$ or $2 \mathrm{~h} / \mathrm{d}$ on semi-desert areas and received corresponding supplemented concentrate to ensure a similar DM on an everyday basis had enhanced average daily gain and fat content in their muscle (Wang et al., 2015).

Table (4): Body weight changes of does affected with grazing time during pregnancy and lactation period.

\begin{tabular}{|c|c|c|c|c|}
\hline \multirow[t]{2}{*}{ Item } & \multicolumn{4}{|c|}{ Experimental group } \\
\hline & G1 & $\mathrm{G} 2$ & G3 & $\pm \mathrm{SE}$ \\
\hline \multicolumn{5}{|c|}{ Body weight, kg (during pregnancy period): } \\
\hline Initial body weight; IBW, Kg & 18.75 & 17.95 & 17.43 & 0.57 \\
\hline First 90 days (early pregnancy), Kg & 20.84 & 19.05 & 18.69 & 0.65 \\
\hline BWC as a percent of IBW, \% & 11.15 & 6.13 & 7.23 & - \\
\hline Second 60days (Before kidding), $\mathrm{Kg}$ & 21.90 & 21.14 & 21.91 & 0.67 \\
\hline BWC as a percent of IBW, $\%$ & 16.80 & 17.77 & 25.70 & - \\
\hline Total pregnancy change, $\mathrm{Kg}$ & $3.15 b$ & 3.19ab & $4.48 \mathrm{a}$ & 0.36 \\
\hline $\mathrm{BWC}$ as a percent of IBW, $\%$ & 16.8 & 17.8 & 25.7 & - \\
\hline After kidding, $\mathrm{Kg}$ & 18.93 & 19.17 & 19.01 & 0.61 \\
\hline BWC as a percent of IBW, \% & 0.96 & 6.80 & 9.06 & - \\
\hline \multicolumn{5}{|l|}{ Birth weight of kidding: } \\
\hline$(\mathrm{Kg})$ & 1.52 & 1.44 & 1.71 & 0.07 \\
\hline$\%$ of does before kidding & 6.94 & 6.81 & 7.90 & 0.33 \\
\hline$\%$ of does after kidding & 8.03 & 7.51 & 9.10 & 0.37 \\
\hline \multicolumn{5}{|l|}{ Body weight, kg (during lactation period): } \\
\hline Early lactation (8weeks ) & 17.41 & 18.50 & 18.88 & 0.54 \\
\hline Late lactation (8weeks) & 19.13 & 16.82 & 19.70 & 1.08 \\
\hline \multicolumn{5}{|l|}{ Body weight change, kg: } \\
\hline Early lactation (8weeks) & -1.52 & -0.67 & -0.13 & 0.36 \\
\hline Late lactation (8weeks) & 1.72 & -1.68 & 0.82 & 0.87 \\
\hline Overall (16weeks ) & 0.20 & -2.35 & 0.69 & 0.67 \\
\hline \multicolumn{5}{|l|}{ Daily body weight change, $g$ : } \\
\hline Early lactation (8weeks) & -27.14 & -11.96 & -2.32 & 6.49 \\
\hline Late lactation (8weeks) & 30.71 & -30 & 14.64 & 14.73 \\
\hline Overall (16 weeks) & 3.57 & -41.96 & 12.32 & 11.46 \\
\hline
\end{tabular}

Means in the same row with different superscripts differ significantly $(P \unlhd 0.05)$

G1: zero hour grazing time; G2:4 hour grazing time; G3:8 hour grazing time. 


\section{Body weight change during lactation:}

Live body weight and body weight changes of does during lactation period as affected by grazing time were presented in Table (4) live body weight was recorded on the first day after kidding, in both early and late lactation period body weight was insignificantly varied among does groups in early lactation period ( 8 weeks). In all treatments, does lost weight with values being-1.52, -0.67 and -0.13 $\mathrm{kg}$ for G1, G2 and G3, respectively, while in late lactation period (8weeks) there were no loses of does weight on G1 (zero hours grazing time) and G3 (8 hours grazing time) although that there were loses of does weight on G2 (4 hours grazing time) only. Daily body weight changes at late lactation were was insignificantly among all treatments, being $30.71,-30$, and $14.64 \mathrm{~g} / \mathrm{d}$ for treatments $\mathrm{G} 1, \mathrm{G} 2$ and G3, respectively.

Similar trends were reported by (Nassar, 2008) who found that body weight was affected significantly by different levels of supplementation (T1;25\%; T2; 50\% of the total requirements and ad lib. level; T3) among does groups in early lactation period (56 days). In all treatment, does lost weight with values being $-1.71,-1.02$ and $-2.73 \mathrm{~kg}$ for $\mathrm{T} 1, \mathrm{~T} 2$ and $\mathrm{T} 3$, respectively, while in late lactation period (56 days) there were no loses of does weight. Daily body weight changes at late lactation were significant $(\mathrm{P} \leq 0.05)$ among all treatments, being $31.61 \mathrm{~g} / \mathrm{d}, 30.36 \mathrm{~g} / \mathrm{d}$, and $18.93 \mathrm{~g} / \mathrm{d}$ for treatments $\mathrm{T} 1$, $\mathrm{T} 2$ and T3, respectively. (Abdou, 2003) found that in early lactation period at 60 days does lose weight with values $-1.0,-1.2$ and $-2.06 \mathrm{~kg}$ for diets (D1, D2 and D3). On the other hand the highest loss was observed in D3 $(-1.42 \mathrm{~kg})$ followed by D2 $(-1.27 \mathrm{~kg})$ and D1 $(-1.12 \mathrm{~kg})$, which is proportionally matched with average milk production. The highest milk yield does reviled the highest weight loss as shown in Table (7) especially during the first stage of milk, while in the last stage of milk G1 and G3 had the ability to compensate for the weight loss, while G2 was still unable to compensate for the weight loss. In dry years when forage availability is decreased, supplementation in the morning may be the most effective way to maintain animal performance. For pasture-based dairy systems, where animals may have restricted grazing time, supplementation in the morning also may be beneficial (Gekara et al., 2005). Moreover, (Mc William, et al., 2004) indicated that one of the mechanisms explains increasing reproductive rate and reducing live weight loss in ewes supplemented with poplar cuttings is the increase of DM and ME consumption; being 0.67, 0.87 and $1.03 \mathrm{~kg}$ total DM/ewe/day and 5.1, 7.0 and 8.5 MJ ME/ewe/day for control, low and high supplemental groups, respectively.

\section{Does reproductive performance and Production index:}

Data of reproductive performance and Production index of does as affected by grazing time were summarized in Table (5). There were 10 does serviced (joined) in each group and recorded 100, 90 and $90 \%$ as conception rate in G1, G2 and G3 respectively, Also kidding rate was 100, 80 and $90 \%$ in G1, G2 and G3 respectively. These results agreed with those reported by (Tedonkeng Pamo et al., 2006) who found that incidences of abortion were much higher in the control (6) than in the supplemented group (1). Furthermore, the group receiving supplementary feed produced more kids (24) than the control (20). More goats aborted in the dry season (5) than in the rainy season (2).

Data of kidding live born were 9, 7 and 7 for G1, G2 and G3 respectively. Similar results were indicated by (Munir et al., 2007) who found that, Sheep under T1 Extensive (grazing only) lost as high as $7.9 \mathrm{~kg}$ body weight during winter. T2 Semi-extensive (grazing plus daily feed supplementation for nine months @ $0.625 \mathrm{~kg} / \mathrm{ewe} /$ day) flock maintained their body weights and T3-Intensive (experimental ration only @ $1.5625 \mathrm{~kg} / \mathrm{ewe} / \mathrm{day}$ ). Achieved significantly higher body weight (i.e. $15.1 \mathrm{~kg}$ ). Highest conception and lambing percentages (93.8\%) were attained under T3 group, followed by T2 (87.5\%) and T1 (75\%). (Hossain et al., 2003) investigated that, the number of grazing pregnant does was higher in high energy supplemented group (11.98MJ ME/kg DM) compared with other two groups (10.02 and $11.06 \mathrm{MJ} \mathrm{ME} / \mathrm{kg} \mathrm{DM})$.

Kids mortality from birth to weaning were $33.33,28.57$ and $71.43 \%$ percentage of live born kids for G1, G2 and G3 respectively, while the much weaned kids were in G1 (6) than G2 (5) and G3 (2). Increasing stillbirth cases and the mortality rate up to weaning with G3 might be attributed to the effect of grazing time and the activity of goat during the grazing. In addition, the higher mortality rate of kids in G3 might be attributed to the high incidence of death when the liter size and birth weight increased as a result for Dystocia. Similar results were indicated by several researchers where (Donkin and Boyazoglu, 2004b) found that the mean annual goat kid mortality was unacceptably high (29\%). The overwhelming reasons for the death of goat kids were coccidiosis and pneumonia, usually occurring together. The high kid mortality was the most significant syndrome affecting goat's production. The 
main losses occurred in the first three months of life. Moreover, (Akingbade et al., 2004) reported that pre-weaning kid mortalities for the natural pasture (NP) treatment group was $30.6 \%$ higher $(55.6 \%$ versus $25.0 \%$ ) than kid mortality recorded in the leucocephala-grass pasture (LGP) treatment group. In most parts of the world, livestock production systems mainly depend on natural vegetation of range and farm lands. Seasonal fluctuations cause a periodical restriction in feed quality and quantity. The majority of lambs are born in spring, while they are weaned towards the warm and dry season when the fodder quality decreases and the available feed does not fully meet the nutrient requirements for early growth (Kamalzadeh et al., 1997). On the other hand, (Donkin and Boyazoglu, 2004a) reported that the main losses occurred in the first three months of life could be attributed to coccidiosis (presumably resulting from overcrowding and poor hygiene), and pneumonia associated with the coccidiosis, But related to poor mothering ability, pendulous udders, overcrowding, and lack of close attendance by the staff responsible. Additional grazing time during the night leads to increased forage intake and consequently provides an opportunity for better animal performance, especially in the dry season when available forage is low. With long day-grazing time in the wet season, night-grazing is less critical.

Table (5): Reproductive performance and Production index of does and kids affected with grazing time.

\begin{tabular}{|c|c|c|c|}
\hline \multirow[t]{2}{*}{ Item } & \multicolumn{3}{|c|}{ Experimental group } \\
\hline & G1 & G2 & G3 \\
\hline Conception rate $\%$ & 100 & 90 & 90 \\
\hline Kidding rate $\%$ & 100 & 80 & 90 \\
\hline Live kids born & 9 & 7 & 7 \\
\hline Kids mortality & 3 & 2 & 5 \\
\hline$\%$ of born alive & 33.33 & 28.57 & 71.43 \\
\hline Weaned kids & 6 & 5 & 2 \\
\hline kids born live / 100 does serviced & 90 & 70 & 70 \\
\hline Kids weaned / 100 does serviced & 60 & 50 & 20 \\
\hline Average birth weight of kids: & 1.52 & 1.44 & 1.71 \\
\hline Average weaning weight of kids: & 5.09 & 5.54 & 5.30 \\
\hline Does production index: & & & \\
\hline Kg born / 100 does serviced & 136.8 & 100.8 & 121.1 \\
\hline Born weight index , \% & 100 & 73.68 & 80.48 \\
\hline Kg weaned / 100 does serviced & 305.4 & 277 & 106 \\
\hline Weaning weight index,$\%$ & 100 & 90.70 & 34.71 \\
\hline
\end{tabular}

Does production index was calculated for the three groups as shown in Table (5) The yield of kids born per 100 serviced does were 90,70 and 70 for G1, G2 and G3, respectively. While kids weaned per 100 serviced does were higher in G1 (60) than G2 (50) and G3 (20). The total weight of kids born (kg) yield per 100 serviced does were 136.8, 121.1 and 100.8 for G1, G3 and G2, respectively. Kids weaned kg per100 serviced does were higher in G1 (305.4) than G2 (277) and G3 (106). These result indicated that the group G1 was higher and G3 was lowest in does production index.

Madibela et al. (2002) indicated that un-supplemented control (UC), continuous supplementation (CS), before rain supplementation (BRS) and after rain supplementation (ARS). Fertility rate, kidding rate, kid survival rate and doe weight at weaning were similar between both treatments and the control. Kid birth weights did not differ between treatment groups. Doe parturition weight was higher in CS and lowest in BRS. Kid average daily gain (ADG) and weaning weight were significantly higher for CS and ARS while they ranked low, but similar between BRS and the control groups. Among ARS animals, doe parturition weight and birth weight tended to be correlated. Kid birth weight was positively correlated with growth rate in the ARS treatment. Productivity index (PI) for CS was high but similar to that of ARS. However PI's for BRS, ARS and the control groups were similar. Similar trends were reported by (Faried et al., 2005) who found that ewes fed ad lib hay and free-choice of concentrates (corn grains and cottonseed meal) from the start of late pregnancy till the weaning of offspring, weaned $1983 \mathrm{~kg}$ of lambs per 100 joined ewes. As the nutritional quality of the roughage decreased, kilograms weaned per 100 joined ewes decreased to $1197 \mathrm{~kg}$ in the hay -straw group and to only $672 \mathrm{~kg}$ in the 
straw -Mufeed group. ( Nassar, 2008) found that different levels of supplementation (T1; 25\%; T2; $50 \%$ of the total requirements and ad lib. level; T3) In addition to birth and weaning weights the yield of kids born per 100 serviced does were 80,125 and 110 for T1, T2 and T3, respectively. While of kids weaned per 100 serviced does were higher in T2 (115) than T3 (90) and T1 (65). The yield of kids born kg per 100 serviced does was 161.6, 217.5 and 187.00 for T1, T2 and T3, respectively. Kids weaned kg per100 serviced does were higher in T2 (837.2) than T3 (680) and T1 (455.7) these result indicated that the group which supplemented with $50 \%$ of total requirement was higher in does production index.

\section{Does milk production:}

Data for milk yield are summarized in Table (6). Milk yield in early lactation were calculated during the first 8 weeks, while the data of milk yield in late lactation was calculated during the second 8 weeks. Milk yield in early lactation was insignificantly varied among the treatments. The highest value of milk yield was recorded in G1 $(14.66 \mathrm{~L})$ followed by G2 being $(12.42 \mathrm{~L})$ and the lowest value was recorded for $\mathrm{G} 3(8.56 \mathrm{~L})$. In the next 8 weeks of lactation period, the values of milk yield were 12.01, 9.24 and $8.34 \mathrm{~L}$ for goat in G1, G2 and G3, respectively.

Table (6): Average milk yield of does affected with grazing time.

\begin{tabular}{lcccc}
\hline & \multicolumn{4}{c}{ Experimental group } \\
\cline { 2 - 5 } & G1 & G2 & G3 & \pm SE \\
\hline Milk yield: & & & & \\
$\quad$ Early lactation, ml ( 8weeks ) & 261.7 & 221.7 & 152.9 & 23.66 \\
$\quad$ Daily, ml & 14.66 & 12.42 & 8.56 & 1.33 \\
$\quad$ Total, L & & & & \\
$\quad$ Late lactation, ml (8weeks) & 214.4 & 165 & 149 & 20.03 \\
$\quad$ Daily, ml & 12.01 & 9.24 & 8.34 & 1.12 \\
$\quad$ Total, L & & & & \\
$\quad$ Entire milk yield, ml ( 16 weeks ) & 476.1 & 386.7 & 301.9 & 42.56 \\
$\quad$ Daily, ml & 26.67 & 21.66 & 16.91 & 2.38 \\
$\quad$ Total, L & 100 & 84.72 & 58.39 & - \\
Relative total milk yield, \%: & 100 & 76.94 & 69.44 & - \\
$\quad$ Early lactation, ml (8weeks) & 100 & 81.21 & 63.40 & - \\
$\quad$ Late lactation, ml (8weeks) & & & &
\end{tabular}

G1: zero hour grazing time; G2: 4 hour grazing time; G3:8 hour grazing time.

On the other hand, total milk yield (16 weeks) was $26.67,21.66$ and $16.91 \mathrm{~L}$ for G1, G2 and G3, respectively. The relative milk yield of G2 and G3 at early lactation was 84.72 and $58.39 \%$ compared to G1 (100\%), respectively. In late lactation the relative milk yield was 76.94and $69.44 \%$ compared to G1 (100\%). The total relative milk yield showed the same trend of early and late lactation which was 81.21 and $63.40 \%$ for G2 and G3 compared to G1 (100\%), respectively. These results are agreed with those reported by (Adogla-Bessa and Aganga, 2000) where the total milk yield up to week 7 were higher for the high energy treatment $(\mathrm{p} \leq 0.01)$ than for the medium or low energy treatments. The average weekly milk production for the entire study period in the goats receiving supplements was almost doubles than that in the control group during the dry season, (Tedonkeng Pamo et al., 2006). Generally sheep and goats are kept extensively in developing countries depending on low productive native breeds. Mainly, goat farming is for milk-meat production while sheep farming is for meat-milk production. (Keskin et al., 2005). Longer distances to pasture may lead to decreases in milk yield, milking frequency, and grazing time of cows in an automatic milking system. (Sporndly and Wredle, 2004). According to the (NRC, 2001), similar results have been observed the increase in energy requirement for walking $2 \mathrm{~km} / \mathrm{d}$ is around $5 \%$ of maintenance, corresponding to approximately 0.5 to 1 $\mathrm{kg}$ of milk. Despite the reduction of pasture intake, it seems that $7 \mathrm{~h} / \mathrm{d}$ of access time to pasture was sufficient for goats to produce their expected milk production, because of the $600 \mathrm{~g} / \mathrm{d}$ of concentrate fed and to the high quality of the pastures (Charpentier, et al., 2019). However, many factors such as grazing conditions and supplementation level may modulate the effect of access time to pasture. For example, under difficult grazing conditions (high temperature and low pasture quality), ewes' milk 
production has been found to be unaffected by access time to pasture between 4 and $7 \mathrm{~h}$ (Valenti et al., 2017). Similarly, the pasture intake and milk production of dairy ewes grazing on good quality legume pastures and highly supplemented $(1400 \mathrm{~g} / \mathrm{head} / \mathrm{d})$ were unaffected by restricting access time to pasture from $6 \mathrm{~h}$ to $4 \mathrm{~h} / \mathrm{d}$ ( Molle et al., 2017). Moreover, access time 8 goats clearly showed a great ability to maintain a long grazing activity from the beginning of the grazing session, with first grazing meal duration close to $4 \mathrm{~h}$, and a progressive reduction of grazing activity until the evening milking (Charpentier and Delagarde, 2018). The fact that no significant difference in milk production was observed between access time 6 and access time 8 suggests that goats have a good ability to adapt their behaviour, or that $6 \mathrm{~h}$ of access time to pasture are sufficient to achieve the potential or expected pasture intake of goats receiving $1 \mathrm{~kg} / \mathrm{d}$ of supplements (Charpentier and Delagarde, 2019).

\section{Kid's performance:}

Data for body weight change and daily gain (Table 7) from birth till weaning of suckling kids indicated that access grazing time of does during pregnancy period affected insignificantly birth weight of kids. Birth weight of kids varied insignificantly among groups. Birth weights of kids were $1.71,1.52$, and $1.44 \mathrm{~kg}$ for G3, G1 and G2, respectively. An increase in birth weight in G3 as a result of an increase in the number of male kids than G1 that contain a smaller number of male kids, while G2 all births were female kids.

The same trend generally, birth weight of male kids in all treatments was higher than birth weight of female kids as reported by (Tedonkeng Pamo et al., 2006) and (Nassar, 2008)

The weaning weight showed a different trend of kids was 5.54, 5.30, and 5.09 kg for G2, G3and G1, respectively. However overall changes $(0-16$ wks.) were insignificantly $(\mathrm{P} \leq 0.05)$ differed among all treatments; being 4.1, 3.59 and $3.57 \mathrm{Kg}$, for $\mathrm{G} 2$, G3 and $\mathrm{G} 1$, respectively.

Table (7): Body weight change and daily gain from birth till weaning of kids suckling does affected with grazing time.

\begin{tabular}{lcccc}
\hline & \multicolumn{4}{c}{ Experimental group } \\
\cline { 2 - 5 } & $\mathrm{G} 1$ & $\mathrm{G} 2$ & $\mathrm{G} 3$ & \pm SE \\
\hline Birth weight, $\mathrm{kg}$ & 1.52 & 1.44 & 1.71 & 0.07 \\
Weaning weight, $\mathrm{kg}$ & 5.09 & 5.54 & 5.30 & 0.27 \\
Total gain, $\mathrm{kg}$ & 3.57 & 4.1 & 3.59 & 0.29 \\
Average daily gain, $\mathrm{g}$ & 31.88 & 36.61 & 32.06 & 2.57 \\
\hline Gl: zero hour grazing time: G2:4 hour grazing time: G3:8 hour grazing time.
\end{tabular}

Average daily gain was calculated through periods along between birth and weaning (0-16 wks.). In general, Average daily gain was between 0-16 wks., the values were as follows 36.61, 32.06 and 31.88 (g/day) for G2, G3and G1 respectively. The decrease in the growth rate of kids is due to the increase in the mortality rate in this period, , which could be referred to less milk production by the end of lactation curve as well as a decrease in milk production

\section{Economic evaluation of does affected with grazing time:}

\section{Economic evaluation for pregnant does:}

Economic evaluation in term of net revenue per doe over feeding expenses presented in Table (8) was calculated to estimate if the grazing time and supplementary feeding through pregnancy is affected on economic evaluation for pregnant does feasible or not. Thus, the live born kids were considered as the main product of pregnant does. The one kg live weight of just live born kid assumed to be EP 100 as market value. From these results, we conclude that all groups were uneconomic, as a result of the high cost of feeding, especially in the G1 with a decrease in birth weight and the absence of twins. As for the G2 and G3, as a result of the increase in mortality during stillbirth and abortion and the decrease in twin cases with a decrease in birth weight, it led to economic inefficiency for female goats during pregnancy and births. 


\section{Economic evaluation of lactating does:}

Economic evaluation in term of net milk revenue per doe over feeding expenses presented in Table (8). It was calculated to estimate if the grazing time and supplementary feeding through lactation is feasible or not. Thus, the milk revenue was considered as the main product of lactating does. The one $\mathrm{kg}$ milk assumed to be EP 15 as market value. The conditions of the range consider as a limiting factor and determine to what extent supplementary feeding and grazing time could be applied. On the other hand, the G1 (zero hours grazing time) for lactating local does supported high milk yield and increased the net revenue through milk production period (16 weeks). Having in milk production G1 was economically feasible increased milk production and payed back in term of money; however the G2 and G3 was more efficient in term of net milk revenue as a percent of feeding cost. And return (offspring + milk) was higher in G1 than G2 and G3 this is due to higher number of kids and milk production. On the contrary, net revenue, EP / Doe was higher in G2 and the next G3 this is due to the decrease cost of feeding values, while the G1, whose cost was higher than other groups.

Table (8): Economic evaluation for dose affected with grazing time.

\begin{tabular}{|c|c|c|c|}
\hline \multirow{2}{*}{ Item } & \multicolumn{3}{|c|}{ Experimental group } \\
\hline & G1 & $\mathrm{G} 2$ & G3 \\
\hline \multicolumn{4}{|l|}{ Economic evaluation for pregnant does } \\
\hline \multicolumn{4}{|l|}{ Whole DMI , Kg/Doe /154d: } \\
\hline Roughage & 74.29 & 52.64 & 62.62 \\
\hline Supplementation & 32.19 & 29.26 & 30.65 \\
\hline \multicolumn{4}{|l|}{ Feeding cost, EP/Doe /154d: } \\
\hline Roughage & 297.2 & 0 & 0 \\
\hline Supplementation & 161 & 146.3 & 153.3 \\
\hline Total Feeding cost , EP & 458.2 & 146.3 & 153.3 \\
\hline Born live return* per Doe, EP & 136.8 & 100.8 & 119.7 \\
\hline Net return per Doe, EP over feeding cost & -321.4 & -45.5 & -33.6 \\
\hline \multicolumn{4}{|l|}{ Economic evaluation of lactating does } \\
\hline \multicolumn{4}{|l|}{ Whole DMI , Kg/Doe /16weeks: } \\
\hline Roughage & 68.02 & 37.80 & 49.91 \\
\hline Supplementation & 24.19 & 20.79 & 21.30 \\
\hline \multicolumn{4}{|l|}{ Feeding cost, EP/ 16 weeks/ per doe: } \\
\hline Roughage & 272.1 & 0 & 0 \\
\hline Supplementation & 121 & 103.95 & 106.5 \\
\hline Total Feeding cost & 393.1 & 103.95 & 106.5 \\
\hline Milk return of 16 week $^{* *}$, EP & 400.1 & 324.9 & 253.7 \\
\hline Net Milk revenue / doe, EP over feeding & 6.95 & 221 & 147.2 \\
\hline Net milk revenue/ doe, $\%$ of feeding cost & 0.02 & 2.13 & 1.38 \\
\hline \multicolumn{4}{|l|}{ Overall economic evaluation / per doe: } \\
\hline Feeding cost (pregnancy + lactation) & 851.3 & 250.3 & 259.8 \\
\hline Return (offspring + milk) & 536.9 & 425.7 & 373.4 \\
\hline Net revenue, EP / Doe & -314.4 & 175.4 & 113.6 \\
\hline \multicolumn{4}{|l|}{ Economic evaluation of growing goat: kids } \\
\hline Net return of weaned kids $* * *, \mathrm{LE} /$ per doe & 181.2 & 176.2 & -19.3 \\
\hline Net return / feeding cost, LE/ per doe & -211.9 & 72.25 & -125.8 \\
\hline \multicolumn{4}{|c|}{ G1: zero hour grazing time; G2: 4 hour grazing time; G3:8 hour grazing time. } \\
\hline $\begin{array}{l}\text { The cost of } 1 \text { Ton of concentrate feed mixture was } \\
\text { EP. } \\
\text { * The live born kids considered as the production } \\
\text { ** Market price for goat's milk was estimated as } \\
\text { *** The assumed } 1 \mathrm{Kg} \text { live weight price for wean }\end{array}$ & ated at 50 & ound) $E$ & n hay 400 \\
\hline
\end{tabular}

\section{Economic evaluation of growing goat kids:}

The economic evaluation of growing goat kids from birth to weaning was calculated as presented in Table (8) Weaned kids feeding cost was calculated through their mothers (suckling does) as a group. 


\section{Nassar}

Recorded data indicated that does received G2 (4 hours grazing time) were more efficient in term of kilogram weight gain from their kids compared to those on G3 (8 hours grazing time) and G1 (zero hours grazing time). This is due to the increase in the number of weaned kids in G2 with the low cost of feeding, while the G1 the number of weaned kids is greater, but the cost of complementary feeding was higher, as well as for the G3, an increase in the proportion of deaths, which led to a decrease in the return from weaned kids.Generally, rearing goat kids on G1 (zero hours grazing time) considers economically infeasible and increase feeding cost without a real payback, and G2 (4 hours grazing time) instead is more feasible.

\section{CONCLUSION}

It can be concluded that, under the conditions of ranges in the Wadi Hadraba region and under drought conditions and the scarcity of rainfall and the fluctuation of its fall from year to year, animals can be grazed for only 4 hours while providing supplementary feeding of $1 \%$ of the body weight and this is more economical efficiency in terms of kids production and milk production, as well as the number of weaned kids, due to the low cost of supplementary feeding, and the local animals in this region have their genetic efficiency to produce kids, twins, and milk production is low compared to other types. Adding more concentrate mixture as supplementary feed for lactating local does was economically infeasible and not payed back in term of money. Further research is required to investigate the feasibility of supplemtary feeding and grazing time for growing kids for meat production. So, we can determine the potential of supplementary feeding for goat's milk and meat production under range conditions.

\section{REFERENCES}

AOAC (1990). Association of Official Analytical Chemists. Official Methods of Analysis. 15th Edition, Washington D.C., USA, 923pp.

Abdou, A. R. (2003). Performance of goats fed halophytic shrubs with organic wastes supplements in Sinai. Ph.D. Thesis, Fac. Of Agric., Cairo Univ., Egypt, 151 pp.

Adogla-Bessa, T. and A. A. Aganga ( 2000). Milk production of Tswana goats fed diets containing different levels of energy. South African Journal of Animal Science, 30 (1):77-81.

Akingbade, A. A.; I. V. Nsahlai and C. D. Morris (2004). Reproductive performance, colostrum and milk constituents of mimosine-adapted South African Nguni goats on Leucaena leucocephala-grass or natural pastures. Small Ruminant Research, 52: 253-260.

Badway, H.S.M. (2005). Nutritional studies on camels grazing the natural ranges of Halaib- Shalateen triangle region Ph.D. Thesis, Fac. of Agric., Cairo Univ. Egypt, 215pp.

Charpentier, A.; H.Caillat; F.Gastal and R.Delagarde (2019). Intake, milk production and grazing behaviour responses of strip-grazing dairy goats to daily access time to pasture and to dehydrated Lucerne supplementation. Livestock Science, 229: 90-97.

Charpentier, A.; and R. Delagarde (2018). Milk production and grazing behaviour responses of alpine dairy goats to daily access time to pasture or to daily pasture allowance on temperate pastures in spring. Small Ruminant Research, 162, 48-56.

Chen, Y.; H. Luo; X. Liu; Z.Wang; Y. Zhang; K. Liu; L. Jiao; Y.Chang and Z. Zuo (2013). Effect of Restricted Grazing Time on the Foraging Behavior and Movement of Tan Sheep Grazed on Desert Steppe. Asian Australas. J. Anim. Sci., 26:711-715.

Claps, S.; R.Rubino; and V. Fedele (1997). Feeding behaviour of grazing and zero-grazing goats fed with the same herbage. In: Lindberg J.E. (ed.), Gonda H.L. (ed.), Ledin I. (Ed.). Recent advances in small ruminant nutrition. Zaragoza: CIHEAM, 1997. p. 79-82 (Options Méditerranéennes : Série A. Séminaires Méditerranéens; n. 34). 
Donkin, E.F. and P. A. Boyazoglu (2004a). Diseases and mortality of adult goats in a South African milk goat herd. South African. Journal of Animal Science, 34 (1):254-257.

Donkin, E. F. and P. A. Boyazoglu (2004b). Diseases and mortality of goat kids in a South African milk goat herd. South African Journal of Animal Science, 34 (1):258-261.

Duncan, D.B. (1955). Multiple ranges and multiple F- test. Biometris, 11: 1-42

El Shaer, H.M. (2002). Range resources inventory and assessment of grazing potential in the South Eastern region of Egypt," A case studies". Proc. of the Regional Workshop for the Africa and North Africa / Middle East regions, 21 - 24 April 2002, Sultanate of Oman.

EMA (1991). Egyptian Meteorological Authority (EMA) No. 12 - October 1991 - Eleventh Congress World Meteorological Organization: Interview with Prof. A. Grammeltvedt Permanent Representative of Norway with the World Meteorological Organization (Issue of WMO Feature, No. 12 [10/01/1991]). Available online: http://nwp.gov.eg/index.php/en/

El-Shaer, H. M.; H. M. Kandil; H. M. Abou El-Naser and H.S. Khamis (1997). Features and constraints of animal resources development in Shalateen-Halaib region. Egyptian Journal of Nutrition and Feeds, 1: 121-128.

Erlinger L. L.; D. R. Tolleson and C. J. Brown (1990) comparison of bite size, biting rate and grazing time of beef heifers from herds distinguished by mature size and rate of maturity. J Anim Sci., 68:3578-3587.

Farid ,M.F.A.; H.S.Khamis; E.Y.A. Eid and A.Helal (2005). Feeding management and the performance of sheep in southern Sinai: 2- reproduction and production performance of the ewe J.Agric. Sci. Mansoura Univ., 30 (12); 7457-7475.

Galal, E. S. E. (1987). Sheep and goats production and research in Egypt. In: Small Ruminant in the Near East. FAO Animal Production and Health Bulletin, 54, 117-155.

Garcez, B. S.; A. A.Alves; D. L. C.Araújo; M. E.Oliveira; R. C. F. F. Pompeu; M. C. P.Rogério; A. L. Moreira and I. S. S. Lima (2019).Performance and grazing behavior of growing goats supplemented with palm tree fruit. Revista Brasileira de Zootecnia, 48:e20180159.

Gekara, O. J.; E. C.Prigge; W. B. Bryan; E. L. Nestor and G.Seidel (2005) time for grazing on forage utilization by lactating beef cows Influence of sward height, daily timing of concentrate supplementation, and restricted. J Anim Sci., 83:1435-1444.

Gibb, M.J.; C.A.Huckle; R.Nuthall and A.J. Rook (1999). The effect of physiological state (lactating or dry) and sward surface height on grazing behaviour and intake by dairy cows. Appl. Anim. Behav. Sci., 63, 269-287.

Goering, H. K. and P. J. Van Soest (1970). Forage Fiber Analysis .Agric. Hand book, No. 379, USDA, Washington, DC, USA, 85pp.

Hegazi, A.M; M.Y.Afifi; M. A. EL-Shorbagy; A.A. Elwan and S. El- Demerdashe (2005) Egyptian National Action Program to Combat Desertification Editorial Board .June, P40.

Hossain, M. E.; M.Shahjalal; M. J. Khan and M. S. Hasanat (2003). Effect of dietary energy supplementation on feed intake, growth and reproductive performance of goats under grazing condition. Pakistan Journal of Nutrition, 2 (3): 159-163.

Kamalzadeh, A.; J.van Bruchem; W. J.Koops; S.Tamminga and D.Zwart (1997) Feed quality restriction and compensatory growth in growing sheep: feed intake, digestion, nitrogen balance and modelling changes in feed efficiency. Livestock Production Science, 52: 209-217.

Keli, A.; L.P.S. Ribeiro; T.A. Gipson; R.Puchala; K.Tesfai; Y. Tsukahara; T.Sahlu and A.L. Goetsch (2017). Effects of pasture access regime on performance, grazing behavior, and energy utilization by alpine goats in early and mid-lactation. Small Ruminant Research, 154, 58-69.

Lebbie, S. H. B. (2004). Goats under household conditions. Small Ruminant Research, 51: 131-136. 


\section{Nassar}

Madibela, O. R.; B. M. Mosimanyana; W. S Boitumelo and T. D. Pelaelo (2002) Effect of supplementation on reproduction of wet season kidding Tswana goats. South African Journal of Animal, 32 (1).

Keskin M.; A. Sahin; O. Bicer; S.Gul; S. Kaya; A. Sari and M. Duru (2005) Feeding Behaviour of Awassi Sheep and Shami (Damascus) Goats. Turk J Vet Anim Sci., 29: 435-439.

McWilliam, E. L.; T. N.Barrya; N.Lopez-Villalobosa; P. N. Cameronb and P. D. Kempc (2005). Effects of willow (Salix) versus poplar (Populus) supplementation on the reproductive performance of ewes grazing low quality drought pasture during mating. Animal Feed Science and Technology, 119: 69-86.

Mohamed A. H. (2018). Using high spatial resolution satellite imagery to evaluate the impact of mesquite invasion on desert rangeland at southeastern Egypt. J. Bio. Env. Sci., 13(3): 167-176.

Mohamed, A.H.; M. A. El-Shesheny and H. S. Badawy (2019) Estimating Grazing Capacity for Desert Rangelands of Wadi Hederbah in Southeastern Egypt. Advances in Environmental Biology, 13(10): 22-31.

Molle,G.;M.Decandia;V.Giovanetti;C.Manca;M.Acciaro;G.Epifani;L.Salis;A.Cabiddu; M.Sitzia and A. Cannas (2017). Grazing behaviour: intake and performance of dairy ewes with restricted access time to berseem clover (Trifolium alexandrinum L.) pasture. Grass For. Sci., 72: 194-210.

Morand-Fehr, P. (2005). Recent developments in goat nutrition and application: A review. Small Ruminant Research, 60: 25-43.

MUNIR, M.; A. W. JASRA and M. A. MIRZA (2007) effects of feeding and management systems on body weight and reproductive performance of balochi ewes Pakistan Vet. J., 27(3): 126-128.

Nassar, M.S. (2008). Nutritional aspects and supplementary feeding for local goats on ranges of halaib and Shalateen region. Ph.D, Fac. Agric. Thesis Cairo Univ.pp104.

Nolan T. and A.S. Nastis (1997) some aspects of the use of vegetation by grazing sheep and goats. In: Lindberg J.E. (ed.), Gonda H.L. (ed.), Ledin I. (Ed.). Recent advances in small ruminant nutrition. Zaragoza: CIHEAM, 1997. p. 11-25 (Options Méditerranéennes: Série A. Séminaires Méditerranéens; n. 34).

NRC (1981). Nutrient Requirements of Goats: Angora, Dairy, and Meat Goats in Temperate and Tropical Countries. National Academy of Sciences, National Research Council. Washington, DC, 91pp.

NRC (2001). Page 20 in Nutrient Requirements of Dairy Cattle. 7th rev. ed. Natl. Acad. Sci., Washington, DC.

Salim, H. M.; M. Shahjalal; A. M. M Tareque and F.Kabir (2002) Effects of Concentrate Supplementation on Growth and Reproductive Performance of Female Sheep and Goats under Grazing Condition. Pakistan Journal of Nutrition, 1(4): 191-193.

SAS (2004). Statistical Analysis System; STAT/ user's guide; Release 9.1; SAS Institute; Cary NC. USA.

Silanikove, N. (2000). The physiological basis of adaptation in goats to harsh environments. Small Rum. Res., 35: 181-193

Soder, K. J.; V. M.Thomas; R. W.Kott; P. G. Hatfield and B.Olson (1995). Influence of energy or protein supplementation during mid-pregnancy on forage intake of ewes grazing Montana winter range. J. Anim. Sci., 73:2853-285.

Sporndly, E.and E. Wredle (2004) Automatic Milking and Grazing-Effects of Distance to Pasture and Level of Supplements on Milk Yield and Cow Behavior J. Dairy Sci., 87:1702-1712.

Taylor, Ch. and M. M. Kothmann (1990). Diet composition of Angora goats in a short duration grazing system. Journal of Range Management, 43: 104-108.

Taylor, N.; P. G Hatfield; B. F. Sowell and G. S. Lewis (2002). Research Note - Influence of supplement form on ewe performance and reproduction. Sheep and Goat Res. J., 17(2): 52-54. 
Tedonkeng Pamo, E.; F. A.Fonteh; F.Tendonkeng ; J. R.Kanaa ; B.Boukila; P. J. Djaga and G. Fomewang (2006). Influence of supplementary feeding with multipurpose leguminous tree leaves on kid growth and milk production in the West African dwarf goat. Small Ruminant Research, 63 (1-2): 142-149.

Tovar-Luna, I.; R.Puchala; T.A.Gipson; G.D. Detweiler; L.J. Dawson; T.Sahlu; A. Keli and A.L. Goetsch ( 2011). Effects of night-locking and stage of production on forage intake, digestion, behavior, and energy utilization by meat goat does grazing grass/legume pasture. Livest. Sci., 140, 225-245.

Valenti, B.; D.Marletta; A.De Angelis; F. Di Paola; S.Bordonaro and M.Avondo (2017). Herbage intake and milk yield in Comisana ewes as effect of $4 \mathrm{vs} 7 \mathrm{~h}$ of grazing during late lactation. Trop. Anim. Health Prod., 49: 989-994.

Van Keulen, J. and B. A. Young (1977). Evaluation of acib insoluble ash as natural marker in ruminant digestibility studies. Journal of Animal Science, 44 (2): 282-287.

Wang, Z., Y.Chen; H.Luo; X. Liu and K. Liu (2015) Influence of Restricted Grazing Time Systems on Productive Performance and Fatty Acid Composition of Longissimus dorsi in Growing Lambs. Asian Australas. J. Anim. Sci., 28:1105-1115.

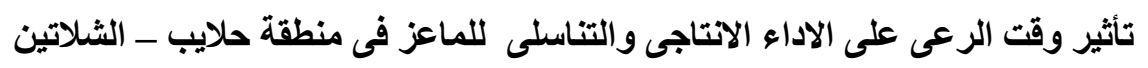

$$
\text { قدمود تغذية الحيوان واللواجن- مركزبحوث الصدراء ص بـ } 11753 \text { ـ المطريةـ القاهرة- مصر. }
$$

أجريت هذه الدراسة بمزرعة الإنتاج الحيواني بوادي حدربة - محطة بحوث الثناتين - مركز بحوث الصحر اءو، على

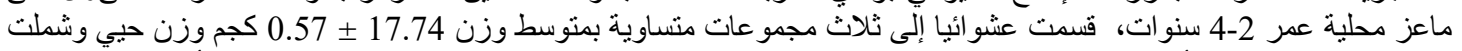

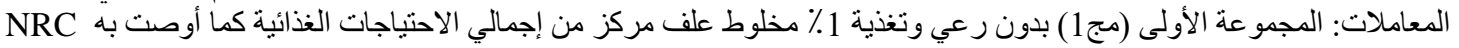

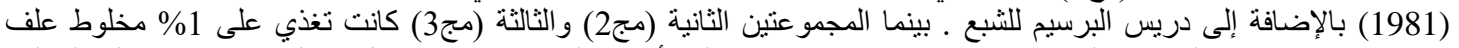

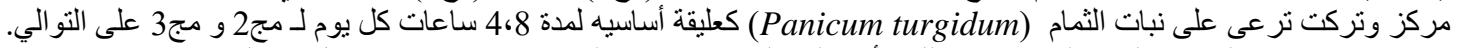

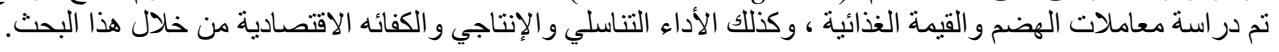

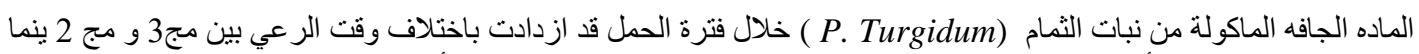

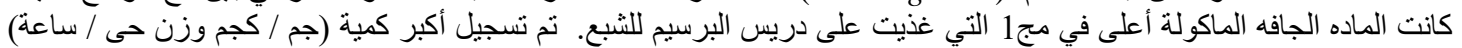

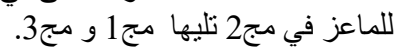

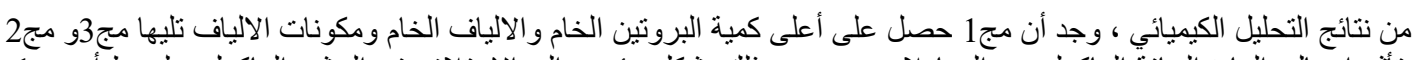

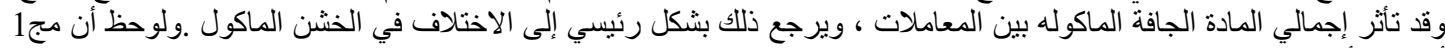

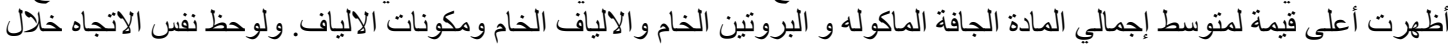
فترة الحليب.

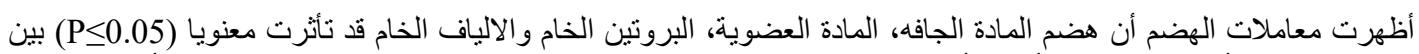

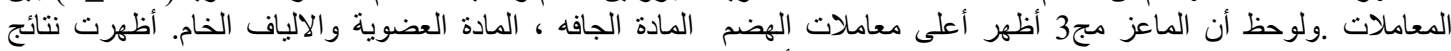

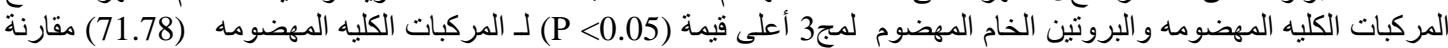

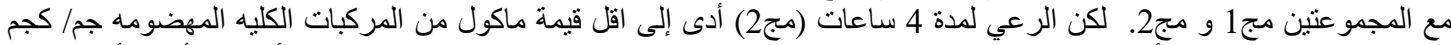

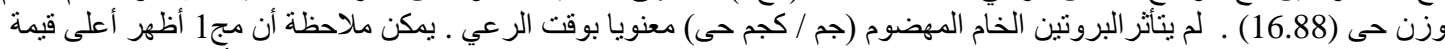

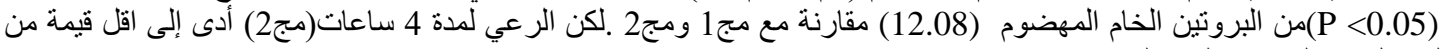

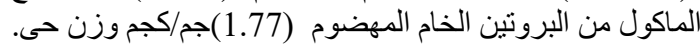

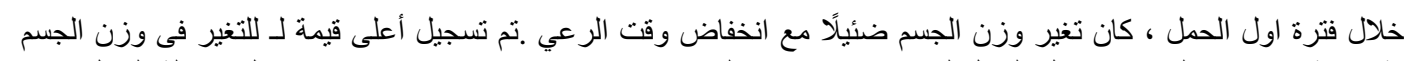

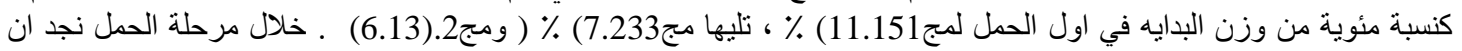

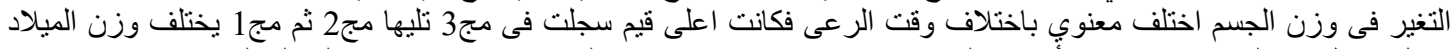

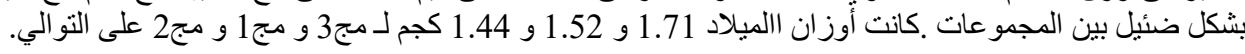

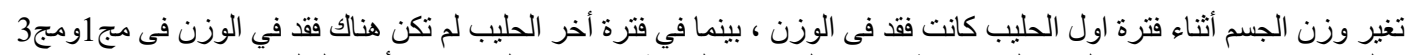

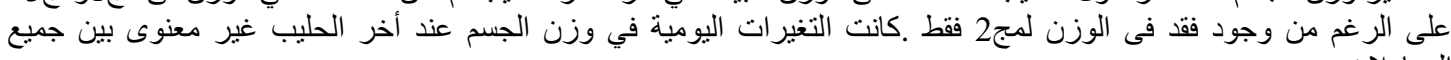
المعامالات الر عت 


\section{Nassar}

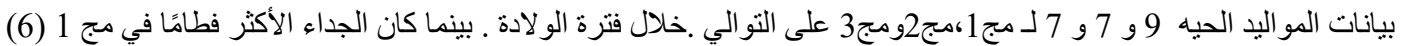

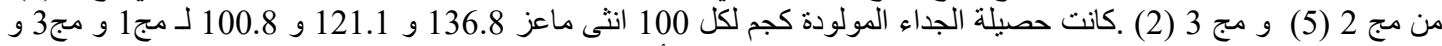

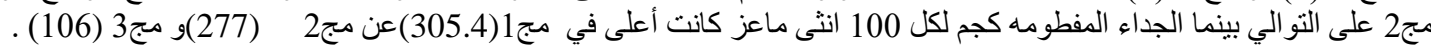

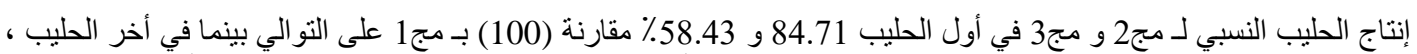

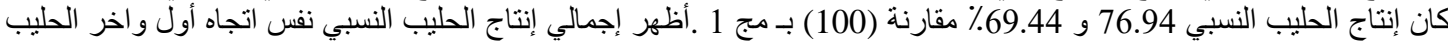

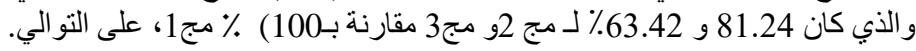

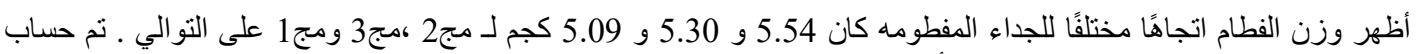

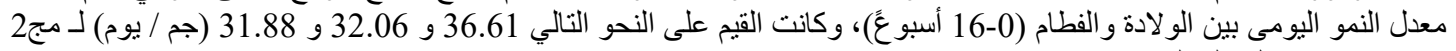

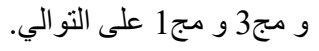

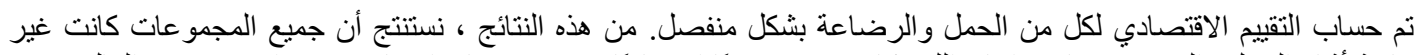

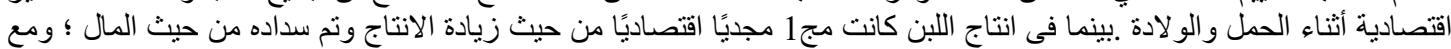

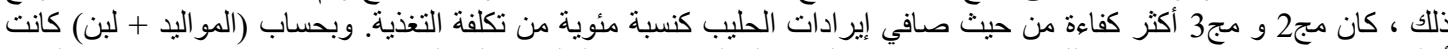

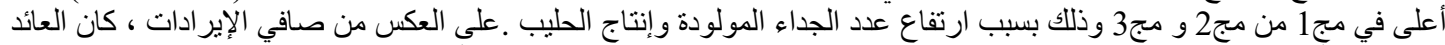

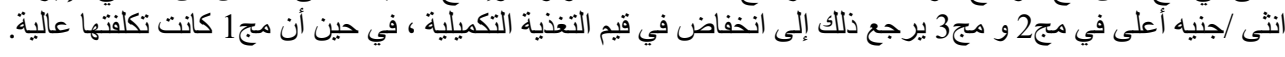

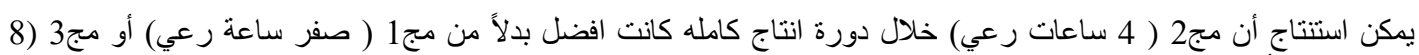

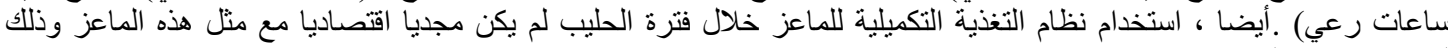
لضعف كفائتها الور اثية. 